\title{
Foundation of the National Institute of Sciences of India
}

$\mathrm{A}^{\mathrm{T}}$ the twenty-first session of the Indian Science A Congress, held at Bombay in the first week of January 1934, the General Committee considered the various suggestions regarding the foundation of an Indian Academy of Sciences that had been made during the previous year, and appointed a representative committee with the object of drafting a constitution to be laid before the next meeting of the Indian Science Congress, and to take necessary steps to bring the Academy into existence.

The General Committee was of opinion (Resolution II) that the principal purposes for which an Indian Academy of Sciences was desirable wero :

(i) To act as a co-ordinating body between scientific societies in India, institutions, and Government scientific departments and services.

(ii) To act as a body of scientific workers of eminence to promote and safeguard the interests of men of science in India and also to act as a National Research Council.

(iii) To publish a comptes rendus of papers read before the Academy and also Memoirs and Transactions.

(iv) To promote and maintain a liaison between men of science and men of letters.

(v) To secure and manage funds and endowments for scientific research.

(vi) To do such other things as may be necessary for the promotion of science in India.

This Committee had an original membership of 24 , which was increased during the year to 39 by co-opting members representing various interests, as was found desirable. The Committee held seven meetings and an emergency meeting. At these meetings the various points of view were considered very carefully and $\mathbf{a}$ scheme for the foundation of a National Institute of Sciences of India was evolved.

In accordance with the direction to take necessary steps to bring the Academy into existence, the Academy Committee had submitted its proposals to a hundred of the leading men of science of India representing all branches of science, and invited them to become its foundation fellows. An additional 25 scientific workers were invited to become foundation fellows on the vote of the first 100 foundation fellows, making a total of 125 foundation fellows. The scheme makes provision for the election of not more than ten ordinary fellows annually, in addition to a certain number of honorary fellows.

This scheme was placed before the General Committee of the Indian Science Congress held on January 3, 1935, and adopted unanimously, together with a recommendation that twenty-five ordinary fellows be elected in the first year instead of ten. The proposal for adoption was moved by Dr. L. L. Fermor on behalf of the Academy Committee and was supported by representatives of the General Committee (Prof. P. N. Ghosh), Asiatic Society of Bengal (Sir U. N. Brahmachari), U.P. Academy of Sciences (Prof. K. N. Bahl) and Indian Academy of Sciences (Prof. B. Venkatesachar).

At the inaugural meeting, which was held on January 7, 1935, Dr. J. H. Hutton, as president of the Indian Science Congress, requested His Excellency Sir John Anderson, Governor of Bengal, to inaugurate the National Institute of Sciences of India.

In inaugurating the first session of the National
Institute of Sciences of India, His Excellency Sir John Anderson referred to the various stages in the progressive organisation of modern science in India. He said that the foundation of a society of varied and comprehensive character, such as the Asiatic Society of Bengal, was the first stage, followed three quarters of a century later by the foundation of universities and specialist scientific services. The third stage was reached half a century later with the foundation of the Indian Science Congress holding annual meetings of individual scientific workers, leading, after the lapse of a quarter of a century, to the foundation of a central and all-India co-ordinating body, the National Institute of Sciences of India, embracing all modern scientific research in India.

His Excellency's speech was followed by the presidential address of Dr. L. L. Fermor, F.R.S., who has been elected its first president. Dr. Fermor traced the history of the development of scientific research in India in the twentieth century, leading up to the formation of the National Institute. He further explained the co-ordinating functions of the National Institute vis-â-vis the Academies of Sciences in India, and the method by which it is proposed to ensure their co-operation. The objects of the National Institute are stated to be "the promotion of natural knowledge in India including its practical application to problems of national welfare", which is indeed a very comprehensive programme.

The Institute will act as a body of men of science of eminence to promote and safeguard the interests of scientific workers of India. By the publication of a comptes rendus containing summaries of the papers read before all Academies of Science in India and by the preparation of an annual report on the progress of science in India in all its branches, it will focus attention on the research work being done in the country and indicate the lines in which progress is desired.

The National Institute will also be prepared to act through properly constituted National Committees in which other learned academies and societies will be associated, and as the National Research Council of India, for undertaking such scientific work of national and international importance as required by the public and by Government. The National Institute and the Academies of Science in India will have mutually complementary functions and will co-operate with each other as independent organisations. The National Institute will thus occupy a very important place in the scientific life of India, and its activities will be a potent factor in India's national progress.

The inaugural meeting was followed by the first ordinary general meeting of the National Institute, which was held on January 8, 1935, in the rooms of the Asiatic Society of Bengal. This meeting was attended by thirty-seven foundation fellows and a large number of visitors from among the members of the Indian Science Congress. The result of the ballot for the election of the first council of the National Institute was announced at this meeting. The Council for 1935 is constituted as follows :

President: Dr. L. L. Fermor, director of the Geological Survey of India, Indian Museum, Calcutta. Vice-Presidents : Brigadier H. J. Couchman, Surveyor-General of India, Calcutta; Prof. B. Sahni, professor of botany, University of Lucknow. 
Treasurer: Dr. S. L. Hora, assistant superintendent, Zoological Survey of India, Indian Museum, Calcutta.

Foreign Secretary: Prof. M. N. Saha, professor of physics, University of Allahabad.

Secretaries : Prof. S. P. Agharkar, Ghose professor of botany, University of Calcutta. Dr. A. M. Heron, superintendent of the Geological Survey of India, Indian Museum, Calcutta.

Members of Council: Mr. M. Afzal Hussain, principal of the Punjab Agricultural College, Lyallpur, Punjab; Mr. T. P. Bhaskara Shastri, director of the Nizamiah Observatory, Begumpet, Hyderabad, Deccan ; Dr. S. S. Bhatnagar, university professor of chemistry and director of the University Chemical Laboratories, Lahore; Mr. B. C. Burt, agricultural expert, Imperial Council of Agricultural Research, New Delhi (and Simla); Prof. J. C. Ghosh, head of the Department of Chemistry, University of Dacca, Ramna, Dacea; Dr. F. H. Gravely, superintendent of the Government Museum, Museum House, Egmore, Madras ; Lieut.-Col. R. Knowles, professor of protozoology, School of Tropical Medicine, Calcutta; Dr. K. S. Krishnan, Mahendralal Sircar professor of physics, Indian Association for the Cultivation of Science, 210 Bow Bazar Street, Calcutta; Prof. S. K. Mitra, Khaira professor of physics, University of Calcutta, University College of Science, Calcutta ; Prof. J. N. Mukherjee, Khaira professor of chemistry, University of Calcutta, University College of Science, Calcutta ; Dr. C. W. B. Normand, director-general of observatories, Meteorological Office, Poona 5; Prof. Ganesh Prasad, Hardinge professor of higher mathematics, University of Calcutta; Dr. Baini Prasad, director of the Zoological Survey of India, Indian Museum, Calcutta ; Sir C. V. Raman, director of the Indian Institute of Science, Bangalore; Lieut.Col. S. S. Sokhey, director of the Haffkine Institute, Parel, Bombay; Lieut.-Col. J. Taylor, director of the Central Research Institute, Kasauli (Simla Hills); Mr. S. C. Trevor, president of the Imperial Forest Research Institute, Dehra Dun; Mr. F. Ware, director of the Imperial Institute of Veterinary Research, Muktesar.

The following representatives, in each case a vicepresident and a member of council, of scientific bodies in India were also appointed:

Asiatic Society of Bengal: Sir U. N. Brahmachari, Medical College Hospital (Retired); Mr. C. C.
Calder, director of the Botanical Survey of India and superintendent of the Royal Botanic Gardens, Sibpur, Howrah.

U.P. Academy of Sciences : Prof. K. N. Bahl, professor of zoology, University of Lucknow; Prof. A. C. Banerji, professor of mathematies, University of Allahabad.

Indian Academy of Sciences : Prof. B. K. Singh, professor of chemistry, Ravenshaw College, Cuttack; Dr. K. V. A. Krishnan, bacteriological research officer, School of Tropical Medicine, Calcutta.

Indian Science Congress Association: Dr. J. H. Hutton, deputy commissioner, Naga Hills, Kohima, Assam; Mr. W. D. West, assistant superintendent of the Geological Survey of India, Indian Museum, Calcutta.

At this first ordinary meeting, eleven papers were read, the titles of which are given below :

(i) "Synopsis of the Pre-Vindhyan Geology of Rajputana" by Dr. A. M. Heron.

(ii) "Physiology, Bionomies and Evolution of the Air-Breathing Fishes of India" by Dr. S. L. Hora. (iii) "Problems of the Solar Corona" by Prof. M. N. Saha.

(iv) "Ionospheric Height Measurements at Allahabad" by Mr. G. R. Toshniwal (communicated by Prof. M. N. Saha).

(v) "On the Electron Theory of Metals" by Dr. R. C. Majumdar, University of Lahore (communicated by Prof. M. N. Saha).

(vi) "On Symmetrical Space with Minimum Rate of Expansion" by Prof. N. R. Sen.

(vii) "New Facts regarding Infection of Citrus colletotrichum gleosporoides" by Dr. H. Chaudhuri, Lahore.

(viii) "Synthetic Enzyme" by Prof. H. K. Sen and Mr. Sobhanlal Banerji.

(ix) "On the Question of the Expansibility of Zero in the Series of Legendre Functions having Nonintegral Parameters" by Prof. Ganesh Prasad.

(x) "On the Cataphoretic Speed and Inorganic Colloids" by Prof. J. N. Mukherjee, Mr. S. G. Chaudhuri and Mr. B. N. Ghosh.

(xi) "Mon and Munda in India and Beyond" by Dr. J. H. Hutton.

It may be confidently expected that the National Institute of Sciences of India will play an increasingly important part in the development of scientific research in India.

\section{Mechanical Testing of Timber}

$\mathrm{I}^{\mathrm{N}}$ September 1928 a committee was appointed by the Committee of the Privy Council for Scientific and Industrial Research to report "On the Mechanical Testing of Timber". This report has now been issued (London : H.M. Stationery Office, 1934). The Committee had its origin as a consequence of work done during the War, in connexion mainly with the design of aircraft, when the testing of timber became a matter of particular importance; as was shown by the amazing development in aircraft construction and reliability. In 1920, a report was published under the auspices of the Aeronautical Research Committee "On the Materials of Construction used in Aircraft and Aircraft Engines", by Lieut.-Col. C. F. Jenkin, professor of engineering science in the University of Oxford. Prof. Jenkin had served as director of the Materials Section of the Technical Department, dealing with the production of aircraft under the Ministry of Munitions. Chap. $x$ of the report dealt with the mechanical properties of timber in a comprehensive manner.

The Committee appointed in 1928 consisted of the late Sir Alfred Ewing (chairman), Prof. C. F. Jenkin, Prof. A. Robertson and Messrs. W. D. Douglas and C. J. Chaplin. The terms of reference were taken as implying "an unrestricted review of the testing of timber for strength and elasticity". This necessarily included consideration in detail of the methods of testing in use at the Forest Products Research Laboratory, Princes Risborough. Various investigations were carried out at this Laboratory during the course of the investigation. Other important experiments were carried out for the Committee by Prof. E. G. Coker in his laboratory at University 